\title{
SURVEY
}

\section{At the Beginning of a History: Visions of the Comintern After the Opening of the Archives}

\author{
BRIGITTE STUDER AND BERTHOLD UNFRIED
}

\section{THE HISTORIOGRAPHY OF THE COMINTERN BEFORE AND AFTER THE OPENING OF THE ARCHIVES}

For a long time the history of communist organizations was primarily written from a party or partisan viewpoint, influenced by topical questions and subjects; ${ }^{1}$ the interpretation or judgements offered were closely linked to the political stance of the author at the time of writing. Even works of a later date and conforming to serious academic standards often came from authors who had experienced communism at first hand. Many of them had been forced to leave Soviet Russia after the revolution. In contrast, others were close to a Communist Party or belonged to disappointed adherents or dissidents of communism - "renegades", as the communist organizations were wont to label those they had expelled and vilified. ${ }^{2}$ The usefulness of works of this kind was not necessarily diminished by virtue of

1 For reasons of space we restrict ourselves to the following works: Margarete BuberNeumann, Kriegsschauplätze der Weltrevolution. Ein Bericht aus der Praxis der Komintern 1919-1943 (Stuttgart-Degerloch, 1967); Ruth Fischer, Stalin and German Communism (Cambridge, MA, 1948); Arthur Rosenberg, A History of Bolshevism. From Marx to the First Five Years' Plan (London, 1934). Interesting memoirs of participants include Margasete Buber-Neumann, Von Potsdam nach Moskau. Stationen eines Irnicgs (Stultgart, 1957); Jules Humbert-Droz, Mémoires, 4 vols (Neuchâtel, 1969-1963); Aino Kuusinen, The Ring of Destiny. Inside Soviet Russia from Lenin to Brezhnev (New York, 1974); Arvo Tuominen, The Bells of the Kremlin. An Experience in Communism (London [etc.], 1983); Herber Wehner, Zeugnis. Persönliche Notizen 1929-19.42 (Bergisch Gladbach, 1984); Ypsilon, Paltern for World Revolution (Chicago [etc.], 1947).

2 See the following exemplary accounts: Aldo Agosti, Terza Internazionalc. La Storia documentaria, 5 vols (Rome, 1974-1979): Franz Borkenau, European Communism (London, 1953); Julius Braunthal, History of the International, 3 vols (London [etc.], 1966, 1967. 1980); Pierre Broué, Le parti bolchevique. Histoire du PC de l'URSS (Paris, 1962); Annie Kriegel, "La IIle Intemationale", in Jacques Droz (ed.), Histoire générale dí socialisme, vol. 3 (Paris, 1977), pp.73-115. An exception in this regard is E.H. Carr, The Twilight of the Comintern, 1930-1935 (London [etc.], 1982). He is one of the few experts who place the history of the Comintem in the framework of Soviet economic and social development. See his A History of Soviet Russia, 14 vols (London [etc.], 1953-1978). Despite some ideological bias, the following anticle offers an informative overview of earlier works on Comintem history: Aldo Agosti, "Historiographie de la 3e Intemationale", Les Cahiers d'histoire de l'Institut de Recherche marxiste, 2 (1980), pp. 7-59. See also Vilém Kahan's bibliography, covering the history of the Third Intemational until 1935, Bibliography' of the Communist International (19/9-1979), vol. 1 (Leiden [etc.], 1990).

International Review of Social History 42 (1997), pp. 419-446 
the fact that the author had been personally involved. Frequently, the insider knowledge presented was not to be found anywhere else. Nonetheless, this constellation of subject matter and personally involved author had obvious disadvantages: the account could not be checked, as Soviet archives were off-limits. Furthermore, the implicit or explicit intention of the author to pronounce a moral verdict on the history of communism meant that the work could be read only as an apologia or as a sweeping condemnation. Of more consequence was a third form of Comintern historiography, namely the one-sided evaluation of ideology and politics, especially the limited focus on the particular "line" and its exponents, the countless changes in tactics, the "deviations", the infighting and splits, the expulsions and resignations.

This deficit proved to be more long-lasting than the others, mostly for reasons inherent in the historiography. The collapse of communism, manifested in political terms by the implosion of the Soviet empire, in historiographical terms by the liberal access policy promoted by Russian archives from 1991 onwards, ${ }^{3}$ made research on the Comintern as a speculative study obsolete. Since then many statements, theories, hypotheses, speculations and deductions have either been confirmed or rejected on the basis of empirical examination. Conducting historical studies of communism in order to find material to buttress, for example Trotskyite or Stalinist positions, is no longer much in evidence. However, the same does not apply to those interpretations which damn unconditionally the history of the world communist movement. With the end of communism and the Cold War, this direction enjoyed a renaissance, portraying the Comintern as a history of conspiracy conducted by ubiquitous and omnipotent Communist Parties. ${ }^{4}$ While Cold War polemics now rarely feature in historical accounts of the development of the Comintern, they are still to be encountered on the field where they really belong: as a vehicle for waging political disputes on the wider stage of television and other popular media. Perhaps the time has come to ask whether and how scholars of communist history, which is now liberated from ideological fetters, have made use of this new freedom.

Archives containing documents of modem history were "conservation depots"s in the Soviet Union. Their use served political ends, and any

${ }^{3}$ On the opening of Soviet archives see Brigitte Studer, Bemhard H. Bayerlein and André Lasserre, "Des archives russes en tant que sources de l'histoire suisse contemporaine". Studien und Quellen (Bem), 20 (1994). pp. 283-313; Nicolas Werth, "De la soviétologie en général et des archives russes en particulier", Le Débat, 7 (1993), pp. 127-144.

"So characterized by Eric Hobsbawm. See his "Radicalism and Revolution in Britain", in Eric Hobsbawm, Revolutionaries. Contemporary Essays (London, paperback ed., 1977), p. 11.

5 The apposite phrase comes from Stefan Creuzberger and Ruud Veltmeijer, "Forschungsarbeit in Moskauer Archiven", Osteuropa (Berlin), 43 (1993), 3, pp. 271. Besides archival material historical relics were also stored. In 1993, for example, the Director of the Russian State Archive showed on television the alleged skull of Adolf Hitler. 
investigations of a historiographical nature were ruled out. From 1987, on a party to party basis, some material on the national sections of the Communist International were de-classified. In late 1991, following the collapse of the Soviet Union, the documentation lodged in Moscow's Russian Centre for the Conservation and Study of Modern History Documents (Rossiiskii Tsentr khraneniya i izucheniya dokumentov noveishei istorii), the former Central Party Archive of the Institute of Marxism-Leninism at the Central Committee of the Communist Party of the Soviet Union, was made generally available, save for a few, historically significant collections. ${ }^{6}$ In addition, the archives of the CPSU for the period after 1952 were made accessible (later, they were again put under lock and key). Under certain circumstances files from the archives of the KGB were also open to examination. Apart from a handful of exceptions made for Russian researchers, the Presidential Archive ("Kremlin Archive") still remains closed to scholars. Papers deposited there include material from the offices of the General Secretary of the Communist Party, including documents which originated during Stalin's reign. ${ }^{\text {? }}$

Being suddenly afforded access to collections hitherto hermetically sealed led historians to ask themselves how they could process the flood of material in any meaningful way. Methodical problems also arose, as the access policy often led, in the initial phase, to a consolidation of the descriptive positivist approach. Due to the widespread and systematic practice within the Comintern to declare documents "secret", 8 it was to be expected that early investigations would centre around establishing the facts. However, the desire to find out "how it really was" turned out to

- For reasons of space we restrict ourselves to this archive (hereafter RTsKhIDNI), as it is the most important source for Western European scholars. For references to other archives see Patricia Grimsted, "Introduction: Russian Archives in the New World Setting", in Archives in Russia. A Brief Directory, Part I: Moscow and St. Petersburg, Intemational Research \& Exchange Board/Committee for Archival Affairs of the Government of the Russian Federation (1992); Markus Wehner, "Archivreform bei leeren Kassen. Einige Anmerkungen zur politischen und ökonomischen Situation der russischen Archive", Osteuropa, 44, 2 (1994), pp. 105-124; Studer et al., "Des archives nusses".

7 Access to these archives is an eminently political matter. Although the "Kremlin" archive is closed to users, documents from there have been quoted on several occasions in Russian periodicals. That must be seen in connection with the activity of the commission appointed by Yeltsin after the coup of August 1991 to collect material for prosecuting and banning the CPSU. Some volumes of documents were obviously published to discredit Gorbachev: see Wehner, "Archivreform bei leeren Kassen", p. 114f. General Dmitrij Volkogonov, the military historian, leading archive functionary and confidant of President Yeltsin, had a monopoly on such archival sources and used them in his biographies of Stalin, Lenin and Trotsky.

'See Brigitte Studer, "Verschleierungstaktik als Herrschaftspraxis. Uber den ProzeB historischer Erkenntnis am Beispiel des Komintemarchivs", Jahrbuch fïr Historische Konmunismusforschung 1995 (1995), pp. 306-321; Berthold Unfried, "Vom Nutzen und Nachteil der Archive fur die Historie. Stalinismusforschung und Komintem-Historiographie nach Öfnung der nussischen Archive", Zeitgeschichte (Vienna), 22, 7-8 (1995), pp. 265-284. 
be an illusion, notwithstanding the extensiveness of the new sources. In comparison to what historians had to rely on before, the documents released seemed to promise much. On the one hand, such pages come direct from the national sections or the power centre itself of the Communist Intemational; ${ }^{9}$ on the other hand, they usually deal with internal party matters which were not disclosed publicly at the time or, if brought to the attention of the specific Communist Party at all, only in increasingly sparing doses. All these documents, then, are marked by the omnipresent atmosphere of mistrust and suspicion cultivated in Comintern circles, especially from the late 1920 s onwards. As a first step, any mention of oppositionist opinion was deleted. Subsequently, in the 1930s, all "deviations" were criminalized and prosecuted. These distortions of reality find their structural reflection in the text, the words of which often conceal more than they purport to say. Many documents are rather testimonials to the hostile imagery in the mind-set prevalent in the Comintern and Soviet leadership of the time than evidence about any one political viewpoint or the oppositional stance of any one party member. When carefully deciphered, however, such passages offer insights into the compulsion exerted on the party faithful to adhere to the codes and models acceptable to Stalinist organizations, into how the self was perceived and presented within an almost perfect system of surveillance. Documents of this kind demonstrate how memory forms and re-forms itself in a culture where the expurgation from memory is an essential part of autocratic power-consolidation.

It thus appears that the facility to approach archival sources with critical caution is needed all the more when working in the Comintern Archive. In order to tease sense out of these papers from a bygone age, it is of equal importance to possess innovative goodwill: experimenting with novel perspectives, formulating new approaches or rephrasing old ones. What is particularly needed is a sensibility for strange and foreign concepts borrowed from cultural anthropology, for example, or an eye for documentary evidence which shows how power relations were structured

- Up to 1991 the following volumes of official documents were available to scholars: Agosti, Terza Internazionale; Jane Degras, The Communist International, 3 vols (London, 1956. 1960, 1965): Theo Pirker, Utopie und Mythos der Weltrevolution. Zur Geschichte der Komintern 1920-1940 (Munich, 1964); Hermann Weber, Die Kommunistische Internationale. Eine Dokumentation (Hanover, 1966). For the protocols of the first two congresses see Pierre Broué, Les congrès de l'Internationale communiste: Du premier au deuxième congrès de l"Internationale communiste, mars 1919-juillet 1920 (Paris, 1979). For intemal documents among private papers (Angelo Tasca), see Giuseppe Berti's essays: "Appunti e ricordi 1919-1926", Annali, 8 (1966); "Problemi del movimento operaio. Scritti critici e storici di Angelo Tasca", Annali, 10 (1968). Documents of a similar nature are to be found in Jules Humbert-Droz, Archives de Jules Humbert-Droz, vols I-III (Dordrecht, 1970, 1983, 1988) and V (Zurich, 1996). For further bibliographical and documentary references see Witold S. Sworakowski, The Communist International and its Front Organizations. A Research Guide of Holdings in American and European Libraries (Stanford, 1965), and Kahan, Bibliography of the Communist International. 
and transported. Sociological methods could explain how political groupings formed and performed, micro-historical tools may provide insights into the fine mesh of social intercourse, those employing gender categories into male-female relationships.

In the first flush of enthusiastic writing after the opening of the archives, the critical attitude to primary sources was often neglected, but the tendency to instrumentalize documents for party-political ends was rarely apparent. Dazzled by the treasures in this Ali Baba cave-system full of dossiers, even historians who were experts in their fields often threw professional caution to the winds. The interest of the media in the fabulous secrets of the archival vaults was soon to dissolve the thin line dividing the writing of history from journalism. It is perfectly legitimate that journalists or historians working as such should have reacted promptly to this public interest in Soviet politics and history. Writing the results in a nonacademic style or how they are presented does not disqualify the journalistic approach per se. The floodlights of mass-media attention, however, gave birth to "investigative" historiography, and some academic historians were a party to the worst excesses of such investigations. One not particularly glorious example concerned a well-known Italian historian: in pirate-like fashion he sold a document on Togliatti he had found in the Comintern Archive to a mass-circulation magazine. The papers from Moscow were later exploited for purely political purposes in the run-up to an Italian election.

"Conspiracy theories" thrived as well, not least those dealing with "Soviet agents", a theme which fascinates the public and commercial publishers alike. ${ }^{10}$ In France, the writer Thierry Wolton caused a sensation by "unmasking" Jean Moulin (the Resistance hero) and Pierre Cot (Minister for the Air in the inter-war Popular Front Government) as NKVD agents on the basis of archival material unearthed in the Russian capital. " During 1992, reports printed in several Westem European newspapers branded the Swiss actor Michel Simon as an agent of the Soviets in the pay of the

${ }^{10}$ See, for example, Pavel A. Sudoplatov, J. Schechter and L. Schechter, The Memoirs of an Unwanted Witness (Boston, 1994). Other studies, while based on more serious research, follow the lines of sensational joumalism: Victor Loupan and Pierre Lorrain, L'argent de Moscou. L'histoire la plus secrètc du PCF (Paris, 1994).

"Thierry Wolton, Le grand recrutement (Paris, 1993). The book provoked a heated debate in the French press, especially the "unmasking" of the national hero Moulin led to widespread condemnation. The historian Pierre Vidal-Naquet led the counter-attack against Wolton, and his book (Le trait empoisonné. Réfexions sur l"affaire Jean Moulin (Paris, 1993)) found acclaim, not only in specialist circles. The family of Pierre Cot took the initative and commissioned a group of historians to examine the historical "evidence" presented by Wolton. In their conclusions they found that Wolton had ignored basic rules of critical methodology, and dismissed his theses. See "Pierre Cot n'était pas un agent soviétique", Le Monde, 25 January 1995; S. Berstein, R. Frank, S. Jansen and N. Werth, Rapport de la Commission d'historiens constimée pour examiner la nature des relations de Pierre Cot avec les autorités sovićtiques (Paris, 1995). 
NKVD or the KGB. ${ }^{12}$ In Germany, a dispute flared up in regard to the Moscow past of the prominent SPD politician Herbert Wehner ${ }^{13}$ Recently, an edition of documents on the history of the CPUSA provoked a controversy among historians. Some criticized the tone of the book, especially its emphasis on the party as an intelligence-gathering agency. ${ }^{14}$ Finally, a very recent example is apparent in the debate about a book on Arthur London whose autobiographical novel L'avell and the film by Costa Gavras made him a symbol for the victims of the show trials after 1945. Drawing on new documentary evidence, the historian Karel Bartosek tries to prove that London, as an apparatchik and a collaborator of the Czech Intelligence Service, was just as much a "culprit" as a victim of Stalinism. ${ }^{15}$

In the area of Comintern historiography, "archival intoxication" sometimes produced a return to trivial models of explanation which depicted "International Communism" and its organization, the Comintern, as the work of a destructive band of adventurers who had diverted Russian history from its "normal" course after 1917. Such highly coloured writing based on new documents is often packaged in historical accounts penned by professional writers or journalists. Exemplary in this connection is a book by Arkadi Vaksberg on the Comintern, in which the author, by drawing on extensive, highly interesting (but unspecified) sources, comes to conclusions which correspond to literary standards and not to those of serious historical scholarship. ${ }^{16}$ Indeed, one gets the impression that Russian studies of Stalinism are characterized by literary or journalistic styles on the one hand, and by fact-oriented academic historiography on the other. ${ }^{17}$

Archival material of the kind lodged in the Comintem Archive do invoke an uncanny form of historical mimicry whereby the reader adapts

12 L'Événement du jeudi, 17-23 December 1992, on the basis of an anticle in the weekly paper The European. See also Le Nouveau Quotidien (Lausanne), 17 November 1992.

13 For example, Fritjof Meyer, "Einsamer Wolf unter Wölfen”, Der Spiegel (nos 12,13/ 1993).

is Harvey Klehr, John Earl Haynes and Friderikh Igorevich Firsov, The Secret World of American Communism (New Haven [etc.], 1995).

is Karel Bartosek, Les Aveux des archives. Prague-Paris-Prague, 1948-1968 (Paris, 1996). The book has immediately provoked a vivid and sometimes violent debate among French historians. As examples for the numerous pro- and contra-statements see, for instance: Denis Peschanski in Libération, 13 November 1996, Alexandre Adler in Le Monde, 15 November 1996, Marc Lazar in Le Monde, 21 November 1996.

${ }_{16}$ Arkadi Vaksberg, Hôtel Lux. Les partis frères au service de l'Internationale communiste (Paris, 1993). His book Die Verfolgten Stalins. Aus den Verliesen des KGB (Reinbek, 1993) is written in a similar vein.

17 For literary works in Russian on Stalinism see John L.H. Keep, "Der Stalinismus in der neueren russischen Literatur", Nene Politische Literatur (Frankfurt a.M.), 40 (1995), pp. 421-440; Wladislaw Hedeler, "Stalinismusforschung in RuBland", in Dic PDS - Herkunft und Selbstverstandnis (Berlin, 1996), pp. 325-333. The Russian historical joumals Istochnik. Istoricheskii Arkhiv and Nauchno-informatsionnyi biulleten' of the RTsKhIDNI regularly publish documents of interest to Comintem scholars. 
the code of conduct documented in the dossiers before him: a policeman's view of history. From the 1930s onwards, the dossiers of the Communist International were compiled on the basis of the inquisitorial logic which was applied to the examination of individual biographies. A primary function was collecting information on communist cadres and monitoring their behaviour. All this was carried out under the Comintern's policy of absolute secrecy, ${ }^{18}$ conditions which have again been imposed in Russian archives. ${ }^{19}$ The observation of secrecy regulations and the omnipresent suspicion surrounded Russian archives like an aura. Characteristically, the process of releasing such documentation is termed de-secretization. The manic practice, widespread in the Comintern, of maintaining strict confidentiality, is reflected in its ultimate form by the historian's race to be the first to disclose what the once "secretized" files contain. In the reading rooms a conspiratorial atmosphere reigns, and the researchers peruse the dossiers with a detective's scrutiny reminiscent of the NKVD operatives who read the same pages sixty years earlier. In this approach, the documents serve as "proof" and the historian makes the archives "confess" a secret history.

The trend to exploit the archival deposits for commercial purposes has waned in direct proportion to the drop in medial interest for events from the Soviet past. While this ensures that the historians concerned now have a less stressful life, ${ }^{20}$ the decline in public curiosity came about just when access to important collections was restricted once more. ${ }^{21}$

\section{PHASES AND DIRECTIONS OF HISTORIOGRAPHY SINCE THE OPENING OF THE ARCHIVES}

One of the first phases was marked by attempts to reconstruct the biographies of victims of Stalinism. This was carried out at the behest of the Communist Parties in the last years of their existence, in order to have

"See Studer, "Verschleierungstaktik".

19 Often the fact that archival material has been made available may not be revealed: "Unfortunately, the author is bound by having signed a confidentiality agreement and therefore cannot refer to archive legends." This introductory remark is from the essay by V.P. Popov, "State Terror in Soviet Russia 1923-1953", Soviet Social Science Review, 35, 5 (1994), p. 48. That Popov cannot quote his sources is especially problematical as his theme centres on the number of victims of the Terror. A sharp controversy surrounds this question: René Ahlberg, for example, has attacked the "low" Terror statistics presented by the Russian scholars Zemskov and Dugin; he accuses them of extrapolating their figures from data which were falsified by the KGB. See Rene Ahlberg, "Stalinistische Vergangenheitsbewältigung. Auseinandersetzung uber die Zahl der GULAG-Opfer". Osteuropa, 42, 11 (1992), pp. 921-937, esp. pp. 924f. Arkadi Vaksberg (Hôtcl Lux) employs a justification similar to that of Popov for not disclosing his archival sources.

${ }^{20}$ For the debate on the "commercialization" of Russian archival material see the discussion forum "Research, Ethics and the Marketplace. The Case of the Russian Archives", Slavic Review, 52, 1 (1993), pp. 87-106.

21 For example, the papers from the Comintem Secretariats of Dimitrov, Manuilsky and Pyatnitsky, available since 1992, were again closed to scholars from January 1995. 
their executed cadres rehabilitated by Soviet or Russian judicial organs. Writing history from the standpoint of the victim, filling out the "blank spots" in communist history, and reassembling biographies of the forgotten were research activities in this first phase. ${ }^{22}$ This period coincided with the last year of the GDR's existence - between the fall of the Berlin Wall and the reunification of Germany. Numerous memoirs, which had often lain in locked drawers for years, were published, as were many articles on the history of the German Communist Party (KPD) and the Comintern. Documents released shortly beforehand in East Berlin or Moscow formed the material for these initial studies. ${ }^{23}$

It soon became clear to the authors of biographically-centred works that the culprit/victim dichotomy they had never questioned was now redundant. A closer look at the tangled network of the Stalinist terror system in the 1930s strongly suggested that the categories of "victims" and "culprits" had become blurred in their outlines and unsuitable as explanatory synonyms. Also now clear was the realization that the mechanical interaction between confessions (in the form of detailed autobiographies written for "the Party") and denunciations, once set in train, proceeded to endanger an ever-increasing circle of persons. Frequently, the informer too was engulfed by the inexorable process. ${ }^{24}$ In these circumstances it is difficult to apportion personal "blame", or to maintain that the innocence of the "victim" is beyond doubt. "Crime and punishment", to use a literary metaphor, are terms which can contribute little to an analysis of the manifold relationships among communist emigrants and Comintern functionaries in the Soviet Union of the 1930s.

2 For publications on German-speaking victims see Institut fur Geschichte der Arbeiterbewegung (ed.), In den Fängen des NKWVD. Deutsche Opfer des stalinistischen Terrors in der UdSSR (Berlin, 1991); Barry McLoughlin and Walter Szevera, Posthum Rehabilitiert. Daten zu 150 Österreichischen Stalin-Opfem (Vienna, 1991); Hans Schafranek (ed.), Die Betrogenen. Osterreicher als Opfer stalinistischen Terrors in der Sowjetunion (Vienna, 1991). In respect of Italian victims see Francesco Bigazzi and Giancarlo Lehner (eds), Dialoghi del Terrore. I processi ai comunisti italiani in Unione Sovietica (1930-1940) (Florence, 1991); and two volumes by Romolo Caccavale, La speranza Stalin. Tragedia dell Antifascismo italiano nell URSS (Rome, 1989) and Comunisti italiani in Unione Sovietica. Proscritti da Mussolini, soppressi da Stalin (Milan, 1995).

${ }^{23}$ For an overall view of these early studies see the volumes 1989/1990f. of Beitrage zur Geschichte der Arbeiterbewegung (Berlin, [etc.]).

${ }^{24}$ These mechanisms of the Terror have been well researched in the meantime: see the detailed analysis in the introduction to Reinhard Muller (ed.), Georg Lukacs, Johannes $R$. Becher, Friedrich Wolf et al. Die Säuberung. Moskau 1936. Stenogramm einer geschlossenen Parteiversammlung (Reinbek, 1991). Before the opening of Russian archives the effects of the Terror on the German-speaking literary emigration in the USSR were already the subject of a masterful analysis in Hans-Albert Walter, "Die Folgen des sowjetischen Staatsterrorismus fur die in der Sowjetunion lebenden Exilierten", in Deutsche Exilliteratur 1933-1950, vol 2: Europaisches Appeasement und thersecische Asylpraxis (Stuttgart, 1984), pp. 203-247. 
Reconstituting the biographies from the world of the Comintern and Stalinism is a phase of historical research not yet ended. Most of the pertinent personalities are either not known at all or have been mentioned solely in hagiographic texts which are of little use to the Comintern scholar. Short biographies, often summarized from cadre-files, are staple items for publication in the Jahrbuch fïr Historische Konmunismusforschung (Berlin). ${ }^{25}$ The research team of the "Maitron" (the monumental dictionary of the French labour movement - Dictionnaire biographique du mouvement ouvrier français) has initiated the international project Dictionmaire biographique du Comintern and intends to include in the publication current work on Comintem biographies, thereby replacing, as a standard work, the reputable volume by Lazitch/Drachkovitch. ${ }^{26}$ Several monographical studies based on the cadre-files in the Comintern have been published, others are being written. ${ }^{27}$

In a second phase, research concentrated on single Communist Parties, whose archival material is usually in Moscow. Scholars found their "own" national section in the masses of papers; on the basis of such investigations

${ }^{25}$ In the category "biographical sketches" (biographische Skizzen) see György Borsányi, "Emo Gerö. Aus dem Leben eines Apparatschiks", Jahrbuch für Historische Kommunismusforschung 1994 (1994), pp. 275-280. However, Borsányi based his findings not on Russian material but on documents from the archive of the Hungarian CP in Budapest. See also Hans Schafranek, "Franz Koritschoner (1892-1941)", Jahrbuch fit Historische Kommunismusforsclung 1995 (1995), pp. 239-261; Boris A. Starkov, "Narkom Ezhov", in John A. Getty and Roberta T. Manning (eds), Stalinist Terror. New Perspectives (Cambridge, 1993), pp. 21-39.

${ }^{26}$ Branko Lazitch and Milorad Drachkovitch, Biographical Dictionary of the Comintern. New, Revised and Expanded Edition (Stanford, 1986; 1st ed. 1973).

"7 For example Harald Wessel, Manzenbergs Ende (Berlin, 1991); Heinrich Kuhnrich, "' 'Ein entsetzliches Mißverständnis' - oder was eigentlich dahinter steckte. Bisher unbekannte Schreiben Munzenbergs an Dimitroff, Oktober 1937", Beiträge zur Geschichte der deutschen Arbeiterbewegung (Berlin), 34 (1992), pp. 66-82; "Les Komintemiens I: Dossier Willi Munzenberg", Communisme (Paris, 1994), pp. 38-39; Reinhard Müller, Die Akie Wehner. Moskau 1937 bis 1941 (Berlin, 1993). Also of interest are Volkogonov's biographies of Stalin, Lenin and Trotsky, as well as a life of Béla Kun based in part on selected material from Moscow's Institute for Marxism-Leninism and published after the resignation of János Kádár, i.e. before the rich amount of material on Kun from the Comintem Archive became generally available. See György Borsányi. The Life of a Conmunist Revolutionary: Béla Kun (New York, 1993). Further biographical studies include Volker Kulow and André Jaroslawski (cds), David Rjdsanow. Marx-Engels-Forscher, Humanist, Dissident (Berlin, 1993); Aldo Agosti, Palmiro Toglianti (Turin, 1996); Pierre Broué, Rakovsky ou la Révolution dans tous les pays (Paris, 1996). Biographical sketches can also be found in Alexander Watlin, Dic Komintern 1919-1929. Historische Studien (Mainz, 1993); Reinhard Muller, "Zenzl Muhsam und die stalinistische Inquisition", in Frauen um Erich Mühisam: Zenzl Mithsam und Franziska zu Reventlow. Schriften der Erich-Mühlsam-Gesellschaff, no. 11 (Malente, 1996), pp. 32-88. Other biographical studies in preparation include Maria Osten and Heinrich Vogeler (by Reinhard Muller), and a volume of documents on Willi Munzenberg (to be published by Links-Verlag, Berlin). Television documentaries on the Comintern milieu surrounding Herben Wehner, Maria Osten and Carola Neher have been broadcast in Germany in recent years. 
a new pattem emerged to document the history of the individual Communist Parties. Following this model, the International Institute of Social History, Amsterdam, coordinated a project on the history of the Comintern's constituent parties. ${ }^{28}$ A second step in this undertaking is oriented towards specific themes in the history of the Communist International. ${ }^{29}$

Two congresses were important for communications between historians of communism. The first one, a symposium held in La Chaux-de-Fonds (Switzerland) on the occasion of the centenary of the birth of Swiss Comintem functionary Jules Humbert-Droz, provided, as early as September 1991, the first overview of current studies since the partial opening of Soviet archives. ${ }^{30}$ Six months later, a well-attended conference in Mannheim (Germany) on "purges" within European Communist Parties since the 1930s, took stock of Stalinism studies to date. ${ }^{31}$

At least two directions of research emerged in respect of the utilization of Russian archival material released in the preceding years. First, to use the new sources to revise accounts of the Comintern's role in general (political history), and to illuminate the history of the power struggle and fractions within the world body. Proceeding along these lines, the researchers hoped to fill in the gaps in Comintern history, and, at a later date, to contribute to a general history underpinned by the new documentation. ${ }^{32}$ The second approach has a different intention - to take the new archival material as the foundation for a history of the rituals and mentalities which permeated the International and the world of Stalinism. The specific phenomena deserving examination in this connection are the (for our modern understanding at least) illogical psychological patterns activated during the various waves of Stalinist repression - faith, conviction, social disciplining and the "production" of standardized personalities. ${ }^{33}$

28 Forthcoming is Jürgen Rojahn (ed.), The Communist International and its National Sections, 1919-1943.

29 A conference with the title "The History of the Comintem in the Light of New Documents" was held in Moscow in October 1994. See the conference report by Reiner Tosstorff, Internationale Wissenschaftliche Korrepondenz zur Geschichte der deutschen Arbeiterbewegung (IWK, Berlin), 31 (1995), pp. 54-58. The conference papers have been published in Mikhail Narinsky and Jürgen Rojahn (eds), Centre and Periphery: The History of the Comintern in the Light of New Documents (Amsterdam, 1996).

${ }^{30}$ See the conference findings in Centenaire Jules Humbert-Droz. Actes du Colloque sur l'Internationale communiste (La Chaux de Fonds, 1992).

31 The conference findings were published in Hermann Weber et al. (eds), Kommunisten verfolgen Kommunisten. Stalinistischer Terror und "Säuberungen" in den kommunistischen Parteien Europas seit den dreißiger Jahren (Berlin, 1993).

${ }^{32}$ For a new overview of Comintem history see Kevin McDermott and Jeremy Agnew, The Comintern. A History of International Communism from Lenin to Stalin (London [etc.], 1996).

${ }^{33}$ Reinhard Muller, "Permanenter Verdacht und 'Zivilhinrichtung'. Zur Genesis der 'Săuberungen' in der KPD", in Weber, Kommunisten verfolgen Kommunisten, pp. 243-264. In March 1996 a symposium took place in the Maison des sciences de l'homme, Paris, on "Nouvelles directions de la recherche sur les années trente en URSS". See the conference 


\section{NEW FINDINGS}

How did historians make use of the new material on the Comintern? What lines of argument have they followed? ${ }^{34}$ Apart from additional information about events in communist history, in particular resolving the mystery behind apparently inexplicable positions taken up by one party or another, ${ }^{35}$ progress has been made in the following areas: the organizational structure of the Comintern; the authority it possessed and how it wielded it; those individuals staffing leading positions in the Executive Committee of the Communist International (ECCI). New insights were also gained concerning the power mechanisms permeating the world movement, the purges it initiated and the reign of terror which followed them. A biographical approach, examining how whole groups of functionaries or individual communists fared, proved to be the most valuable access for researchers. ${ }^{36}$ Our lack of knowledge in this area was quite considerable; the factual data acquired in the last few years was urgently needed to proceed further. In the following pages we wish to deal with new findings in connection with the Comintern's structures and its officials, study the relationship between the Moscow centre and the periphery, and discuss how power mechanisms functioned within the global organization. Finally, we draw the reader's attention to ongoing debates and research desiderata.

\section{The Comintern Apparat and its Cadres}

At first, the framework of the international organization of communism became clearer. It was subsequently possible to describe the apparat in great detail, including the countless attempts to restructure it. The complex diagram of the Comintern's structure was gradually disclosed, providing an overview of an organization which was multifunctional, geographically widespread and changing its shape time and again. ${ }^{37}$ Authoritative bodies

report by Nicolas Werh, Le Bulletin de l'IHTP, 65 (1996), pp. 52-58. See also the special number of Conmmunisme, 42-44 (1996): "Les archives: la nouvelle histoire de l'URSS".

${ }^{3}$ The latest research findings from the German-speaking countries can be found in the Jahrbuch fitr Historische Kommunismusforschung or The International Newsletter of Historical Studies on Comintern, Communism and Stalinism (Cologne). Based on material from the Comintem and KGB archives, see a comprehensive study of Austrian political refugees and skilled workers in the Soviet Union: Barry McLoughlin, Hans Schafranek and Walter Szevera, Aufbruch-Hoffnung-Endstation. Osterreicherinnen und Osterreicher in der Sowjetunion, 1925-1945 (Vienna, 1997).

${ }^{35}$ See the section "The 'Centre' and the Periphery" on pp. 432-434.

${ }^{36}$ Especially in studies on those who participated in the Terror at its highest level. See Starkov, Narkom Ezhov; Amy Knight, Beria. Stalin's First Lieutenamt (Princeton, 1993). The involvement of high Comintem officials in the Terror is analysed in Muller, Die Akte Weliner.

${ }^{37}$ For a description of the Comintern's offshoot organizations (e.g. Intermational Red Aid) see Carola Tischler, Die UdSSR und die Politemigration. Das deutsche Exil in der Sowjetu- 
and numerous committees, hitherto unknown, emerged from the documents. ${ }^{38}$ Many functionaries, whether cadres or employees of the Comintern, regained their historical place in the scheme of things. Previously, only the most important leaders and the foreign staff of ECCI were identified with name and function. Now it is possible to examine who the staff employees were, what they did and what happened to them. The Communist International had, on average, approximately 400 persons on its payroll, but the number varied greatly over the years.

New data from the Comintern Archive, while disclosing new details on the size and tasks of various ECCI departments and subcommittees, also offers three important insights into the forms of organization ECCI took on at different stages. First, the reorganization of 1935 which introduced the centralization of administrative duties and placed the central bodies dealing with the national sections on a geographical basis (Län-dersekretariate) under the personal responsibility of prominent foreign communists (Togliatti, Marty, Gottwald, etc.). Second, the bureaucracy was subjected to new criteria of efficiency and performance, ${ }^{39}$ and third, the syllabus of cadre education was decided and reorganized according to changing needs.

The pyramidal structure introduced after the 7th World Congress (1935) made it feasible to delegate most decisions to the pertinent committee on the respective hierarchical scale. In addition, the most important questions were taken up at the level of the Secretariats. The main benefit of this structural reform was that the ECCI leadership was freed from having to discuss matters of secondary importance. A further result was the general rise in the efficiency of the entire apparat. By examining documents made available of late we can now apprise ourselves of the degree to which the Comintern of the 1930s was managed according to quasi-entrepreneurial,

nion zwischen KPD, Komintern und sowjetischer Staatsmacht (1933 bis 1945) (Kassel, 1995). Reiner Tosstorff (Frankfurt a.M.) is preparing a major publication on the history of the Intemational of Red Labour Unions (Profintern).

38 For the transformation of the Comintern's organizational structure see the contributions in Narinsky and Rojahn, Centre and Periphery; Brigitte Studer, Un parti sous influence. Le Parti communiste suisse, une section du Komintern, 1931 d̀ 1939 (Lausanne, 1994), pp. 153-172; Bemhard H. Bayerlein, "Die 'Central Bodies' und der intemationale Apparat der Kommunistischen Internationale als Problem der Forschung", in Rojahn, The Communist International and its National Sections (forthcoming). An overview of the different Comintern bodies, with references to their archival collections, are provided in the catalogue of the Comintem Archive in RTsKhIDNI. See Kratkii Putevoditel', Fondy i Kollektsii sobranny'e Tsentral'nym partiinym arkhivom (Moscow, 1993).

${ }^{39}$ See the publication of the internal documents drawing the details of this reorganization by Brigitte Studer: "Die Komintemstruktur nach dem 7. Weltkongreß. Das Protokoll des Sekretariats des EKKI uber die Reorganisierung des Apparates des EKKJ, 2. Oktober 1935", Internationale Wissenschaftliche Korrespondenz zur Geschichte der deutschen Arbeiterbewegung, 31 (1995), pp. 25-53; and the essay "More Autonomy for the National Sections? The Reorganization of the ECCI after the Seventh World Congress", in Narinsky and Rojahn, Centre and Periphery, pp. 102-113. 
market-oriented standards. Contradicting the self-image it projected (an idealistically motivated community of common interest), the Comintern was a concern run strictly on the division of labour, with concomitant rationalization practices to reduce its technical and administrative staff. Changes are also visible in the many attempts at reorganizing the apparat since 1926, or in the "think tanks" which suggested such changes. Discipline at the workplace was reinforced by introducing strict regulations to supervise punctuality, orderly work practices and productivity. Some of the control mechanisms, clocking in or out, for example, were reminiscent of Taylorist concepts prevalent in the huge plants of the capitalist world. Borrowing ideas from such a source was certainly no accident, as American production methods had model character for Soviet industry in the 1930s. Other regulations for employees, such as sanctions or salary reductions imposed for unexcused absence from work or even in case of sickness, show that Comintern bureaucrats, in their methods to enforce compliance and discipline, did not hesitate to employ disciplinary methods borrowed from the age of nascent capitalism.

A view inside the Moscow headquarters of the Comintern also produces information on the tasks and identities of employees in lower positions. Similarly, the responsibilities assigned to Heads of Departments known by name become clear and their biographies can now be added to or revised. ${ }^{40}$ New cadres confront the reader, giving, for the first time, names, figures and information on how the apparat was "russified". These new data enhance rather than contradict what was previously known about this process, especially the employment of an increasing number of Russian communists during the "Stalinization" of the Comintern from the end of the 1920s. ${ }^{41}$ This "unfriendly take-over" can be traced not least by examining the change in the recruitment policy of the Comintern. ${ }^{42}$

The so-called "cadre files" comprise one of the most extensive collections in the Comintern Archive. In the course of his or her political life, a party cadre was obliged to write down a political curriculum vitae on

\section{${ }^{40}$ See Muller, Die Alte Wehner.}

"See Fridrikh Firsov, "Mechanism of Power Realization in the Comintern", in Centenaire Jules Humbert-Droz, pp. 449-466. Other details are provided by Studer, Un parti sous influence, pp. 155-172, and in Peter Huber, "Der Moskauer Apparat der Komintern: Geschäftsabteilung, Personalentscheide und Mitarbeiterstand", Jahrbuch für Historische Kommunismusforschung 1995, pp. 147-150.

12 Prior to the opening of Russian archives data on some 700-800 Comintem staff members were known. See Lazitch and Drachkovitch, Biographical Dictionary, and Degras, The Communist International. In two articles for the International Review of Social History: Vilém Kahan offered supplementary data on Comintem officials: "The Communist International, 1919-1943: The Personnel of its Highest Bodies", XXI (1976), pp. 151-185; "A Contribution to the Identification of the Pseudonyms Used in the Minutes and Reports of the Communist Intemational", XXIII (1978), pp. 177-192. The heavily Russian composition of key bodies, in the secretariats of the party cells in ECCI, for example, was a well-kept secret until recently. 
numerous occasions, sometimes on preprinted questionnaires. The Cadres Department of ECCI collected these papers, along with any other pertinent material, and placed them in personal dossiers. Reports on individuals, assessments and even denunciations found their way into the files. ${ }^{43}$ Elements of individual or collective biography can now be examined as they stand or used, en masse, to analyse "party" biographies not only as a collation of data documenting a person's political development, but:

- as biographical passages designed to comply not with subjective experience, but with what was felt to be the linearly correct political development of a militant party member;

- as component parts of a prototype biography representative of a whole generation of fighters for Stalin's brand of communism.

Cadre material emanating from ECCI's many school courses delineates how party members were drilled to be conformist party functionaries. How various institutions of the Comintern were employed to impart a system of Stalinist values has received much scholarly attention recently, in particular the development, aims, extent and financial costs of such schooling. ${ }^{44}$ For years the only knowledge available on the Comintern's secret institutions of learning was to be found in memoirs, but now the original documents can be examined in full.

\section{The "Centre" and the Periphery}

In any historical examination of the Comintern as an organization to promote Soviet dominance, a key question centres around the relationship between the apparat in Moscow and the numerous national sections. Documents now accessible reveal concisely how the centralization and "russification" policies within the International made the sections increasingly dependent on Moscow. The mechanisms in play to impose conformity, especially in the period of "bolshevization" from the mid-1920s, were common knowledge to interested readers for many years. Specialists now know that the leeway allowed any one Communist Party was constricted further in the 1930s, on several levels and at an accelerating pace. Comintern headquarters accorded more competence to ECCI departments, while simultaneously usurping additional powers of decisions for its own Executive. Consequently, the influence of the Communist Parties on overall policy and their consultative role were restricted, as the only information

\footnotetext{
43 The thick dossier on Herbert Wehner, for example, was the foundation for Reinhard Muller's book, Die Akte Wehner.

" Some studies have been published on ECCI's schools. For examples of first results gleaned from Comintern documents on this complex, see Leonid Babitchenko, "Die Kaderschulung der Komintem", Jahrbuch fit Historische Kommunismusforschung 1993 (1993), pp. 37-59. Hans Schafranek's chapter on Austrians at the Intemational Lenin School in McLoughlin et al., Aufbruch-Hoffnung-Endstation, and Studer, Un parti sous influence, pp. 230-249.
} 
which flowed from the Russian centre was that which the Comintern leadership considered to be in its own interest. Nonetheless, when appraising these new documents one should avoid the temptation of seeing the relationship between the Comintern and its national sections solely from a Moscow perspective; it would be a distortion to underplay the national role the parties played in the workers' and, consequently, in the national cultures of their own countries.

Still to be analysed is the extent to which ECCI shaped the politics of the parties in specific cases. Drawing on new material it is now possible to make definite statements about two examples often discussed in the historiography of the Communist International: the attempts to legalize the French Communist Party (PCF) under the conditions of German occupation in the summer of 1940, and the Salerno "about-turn" of the Italian Party (PCI) four years later. As regards the first example, it has emerged that extensive contacts between officials of the PCF and the German authorities in France were initiated by party functionaries, who were subsequently told to "back off" by the Comintern. ${ }^{45}$ The svolta di Salerno concerns the change in tactics by the PCI carried through by Togliatti after his return from the Soviet Union: a policy of national unity, including the willingness to enter Badoglio's government. Basing his arguments on documents found in the Comintem Archive, the Russian historian Mikhail Narinsky attempted to prove that Stalin himself had ordered this volte-face in the interests of Soviet foreign policy. ${ }^{46}$ "The Salerno tactical about-turn was on Stalin's orders", so ran the headline in Corriere della sera shortly afterwards. In his critique, Aldo Agosti found fault with this onedimensional slant (overemphasis of the Moscow perspective) of Narinsky's piece, but did not disagree that the change in policy would have been impossible without Stalin's consent. However, Agosti held that the decision reached by Togliatti happened to tally with Soviet foreign policy goals, so that the Salerno about-tum was as much Togliatti's concept as it was Stalin's. ${ }^{47}$

\footnotetext{
${ }^{45}$ See the essays by Stéphane Courtois ("Un été 1940. Les négociations entre le PCF et l'occupant allemand a la lumière des archives de l'Internationale communiste"), Mikhail Narinsky ("Le Komintem et le Parti communiste français 1939-1941") and Yves Santamaria ("Le Parti, la France et la guerre. De la paix de Moscou à l'armistice de Rethondes, mars-juin 1940"), all in Communisme (1992-1993), pp. 11-127 and Stéphane Courtois and Mare Lazar, Histoire du Parti conmmuniste français (Paris, 1995), pp. 74-76.

${ }^{46}$ Mikhail M. Narinsky. "Togliatti, Stalin e la svolta di Salemo", Studi storici (Roma), 35,3 (1994), pp. 657-666. This article, by the way, is a good example of how the "hierarchization" of archival access operates in Russia. Narinsky, as Assistant Director of the Institute for World History in the Academy of Sciences, was obviously deemed high enough in rank to be allowed to quote from documents kept in the exclusive "President's Archive". The most important document for his study was not shown to him, however, forcing him to extrapolate indirectly.

4 Aldo Agosti, Liberazione, 2 April 1995. See also the chapter, "Alle scaturigini della svolta di Salemo", in Giuseppe Vacca, Togliatti sconosciuto (Rome, 1994), pp. 67-74.
} 
Although the dependency of the national sections on the Soviet centre is underlined time and again by the new documents, the formula "orders from Moscow" does not do full justice to the complexity of these relations. Gradually bringing the national sections to heel by means of centralizing policies was not the work of ECCI alone; ${ }^{48}$ in many cases this process was initiated and accelerated by single Communist Parties. Sharing a common political goal and being bound to Moscow on many levels, the national sections were inclined to view the centralization tendencies enforced by ECCI as appropriate and efficient measures, which they should promote in their own countries as well. ${ }^{49}$ In order to understand what bonded Western European communists to their ideological home in Moscow, attention must be paid to the following areas:

1 the ideological-political nexus as a constituent part of a unified ideological architecture based on programmes agreed upon and common goals;

2 the structural nexus between centre and periphery forged by the Intemational's highly centralized organization;

3 the personal nexus forged by the transfer of cadres from Moscow to the head offices of the Communist Parties in Western Europe;

4 the cultural attachment forged by an emotional and intellectual identity with a Stalinist "way of life". so

\section{Power Mechanismis and Terror}

Parallel to the shift in power upwards within the organization, the Comintern had to accede competence to outside bodies. How the outside interference was brought to bear is not yet altogether clear, mainly for two reasons. First, because it operated on the basis of personal contacts, especially those between Stalin and Dimitrov, as the excerpts from the latter's diary and other material recently published have shown. ${ }^{31}$ Second, the loss of the Comintern's control over its own affairs was decisively influenced

\footnotetext{
${ }^{48}$ Whereas the term "centre" is useful in illuminating the relations between the national sections and the Comintern apparat, it can lead to an optical deception: within world communism ECCI was a prominently placed authority, behind which, however, the growing influence of the CPSU in international communist affairs, and the power of the Soviet Union itself and its state apparalus lay hidden from view.

${ }^{49}$ For a more detailed account see Brigitte Studer, "Zwischen Zwang und Eigeninteresse. Die Komintern der dreissiger Jahre als Machtsystem und Sinnhorizont", Traverse, 3 (1995), pp. $46-62$.

so These levels of adherence are discussed in Studer, Un parti sous influence.

${ }^{31}$ Extracts from Dimitrov's diary were published in Sovershenno sehretno (Moscow), 12 (1990), pp. 18-20; Novaya i noveishaya istoriya, 4 (1991), pp. 63-74; Letopisi (Sofia), $11-$ 12 (1992), pp. 56-77; Epochi (Sofia), 3-4 (1993), pp. 114-128. See also Oleg Khlevniuk, Le cercle du Kremlin. Staline et la Bureau politique dans les années trente: les jeux du ponvoir (Paris, 1995); Lars T. Lih, Oleg V. Khlevniuk and Oleg V. Naumov (eds), Stalin's Letters to Molotov, 1925-1936 (New Haven [etc.], 1995).
} 
by the installation of "secret" administrative units, as Niels Erik Rosenfeldt calls them, within the ECCI apparat. ${ }^{52}$ Some references to "special departments" within the Communist International have been unearthed: from 1932 these clandestine units worked hand in hand with the Cadres Department. ${ }^{53}$ Historians writing on Soviet social history describe how the NKVD set up secret structures in industry and educational institutions. The secret police directed these units to collect "incriminating" information on individuals, and used such documents in the purges which followed. ${ }^{54}$ Equally well known for some time is that certain Comintern cadres worked for the NKVD or had been high-ranking secret policemen beforehand. Meier Moskvin (Mikhail Trilisser), elected in 1935 to the Presidium and Secretariat of ECCI, is a case in point.

Of more fundamental significance was the reshuffle of priorities which transformed the apparat into a police-like surveillance corps. Hitherto, observation was conducted to monitor loyalty to "the Party line"; now the organs involved - the Cadres Department, the International ControlCommission and the Russian Party cells in ECCI - became central agencies of repression. ${ }^{\text {ss }}$ All other Comintern organizations and offices applied their efforts to serve the logic of the purges. Each cadre saw his or her distorted, yet unmistakable self reflected in the many questionnaires, reports, autobiographies and accounts of "criticism and self-criticism" sessions which these organs produced and exchanged on a departmental basis. $^{36}$ The perception of oneself held by others influenced selfperception, which, in turn, influenced how one saw others. Papers from the cadre files or stenograms documenting "purge" meetings leave the reader in no doubt that, in a spiral of suspicion, denunciation, expulsion from the party and arrest, the individual could not stand aside or escape

${ }^{52}$ Niels Erik Rosenfeldt, Stalin's Secret Chancellery and the Comintern. Evidence about the Organizational Patterns (Copenhagen, 1991).

${ }^{33}$ For example "Instruktion uber die innere Arbeitsorganisation der Kaderabteilung und die Beziehung mit der Spezialabteilung und den Ländersekretariaten", February 1932, RTsKhIDNI, 495/18/945. See also Studer, Un parti sous influence, pp. 155-156.

${ }^{34}$ See Stephen Kotkin, Magnetic Mountain, Stalinism as a Civilization (Berkeley, 1995) and idem, "Coercion and Identity: Workers' Lives in Stalin"s Showcase City", in Lewis H. Siegelbaum and Ronald Grigor Suny (eds), Making Workers Soviet: Power, Class and Identity (Ithaca, 1994), pp. 274-310.

ss Rosenfeldt, Stalin's Secret Chancellery; Fridrich Fitsov, "Die 'Säuberungen' im Apparat der Komintern", in Weber, Kommunisten verfolgen Kommumisten, pp. 37-51; Peter Huber, Stalins Schatten in die Schweiz. Schwcizer Kommunisten in Moskau: Gefangene und Verteidiger der Komintern (Zurich, 1994), pp. 17-57. For an (incomplete) review of recent publications on this theme see Kevin McDermott, "Stalinist Terror in the Comintem: New Perspectives", Journal of Contemporary History, 30 (1995), pp. 111-130.

${ }^{36}$ See Muller, Die Sauberung, Moskan 1936, and the analysis of these rituals written by Berthold Unfried in two articles: "Rituale von Konfession and Selbstkritik: Bilder vom stalinistischen Kader", Jahrbuch fir Historische Kommumismusforschung 1994 (1994), pp. 148-164, and "Dic Konstituierung des stalinistischen Kaders in "Kritik und Selbstkritik" ",

Traverse, 3 (1995), pp. 71-88. 
taking sides - neither the unambiguously guilty culprits nor their victims. Furthermore, the informer was also under constant observation and could face arrest and prosecution. This was often the case with those who had carried out the ominous "review" of cadres. ${ }^{57}$ Such was the background, the prelude to the massacre of foreign communists in the Soviet Union from 1935 onwards, a theme which has always fascinated those researching into the history of communism. Focusing on this "Shakespearian" finale of the world movement, however, obscures the marginalized role accorded to the Comintern in its last years. What party courts liquidated in a crescendo of monstrous accusations was but the shadow of a global force, which once, not least as a welcome ally assisting the various factions battling for power in the Soviet leadership, was purported to function as the motor of world revolution. From the beginning of the 1930s the Comintern gradually lost autonomy, and the 7th World Congress marked the last stage on the road to political oblivion. ${ }^{58}$ As mentioned earlier, at this last congress of the Communist International, Yeshov and Moskvin, leading figures in the secret police NKVD, were elected to ECCI. In the next three years they oversaw the liquidation of the Comintern apparat. This wilful destruction of the movement in terms of organizational structures and human life has been analysed in some recent studies. In particular, we are indebted to Russian historians for drawing our attention to the planned, but never realized staging of a fourth great show trial - this time against the Comintern elite. ${ }^{59}$

New documents published by Reinhard Muller confirm the thesis, first formulated by Fridrikh Firsov and Boris Starkov, that the dynamic of the Terror had yet one more stage to complete. ${ }^{0}$ Chosen as the main defendants in the trial of the so-called "Anti-Comintern Block" were Pyatnitsky, Knorin and Béla Kun. Others awaiting prosecutions charges included further high-ranking officials and staff members from the various Secretariats, the Cadres Department and the conspiratorial unit for international

${ }^{37}$ Muller, Die Akre Wehner. These party meetings are treated at some length in: Wolfgang Leonhard, Child of the Revolution (London, 1957); Jelena Bonner, Mittter und Töchter. Erinnerungen an meine Jugend 1923 bis 1945 (Munich [etc.], 1992), pp. 170-175. The case of the Swiss cadre Sophie Kirschbaum is described in Studer, Un parti sous influence, pp. 262-279.

${ }^{8}$ A process delineated in Carr, Twilight of the Comintern.

59 Firsov, "Die 'Säuberungen' im Apparal der Komintem", in Weber, Kommunisten verfolgen Kommunisten, pp. 37-51; Boris A. Starkov, "The Trial That Was Not Held", Europe-Asia Studies (formerly Soviet Studies), 46, 8 (1994), pp. 1297-1315.

${ }^{60}$ Reinhard Muller, "Der Fall des 'Antikomintern-Blocks' - Ein vierter Moskauer Schauprozeß?", Jahrbuch filr Historische Kommunismusforschung 1996 (Berlin, 1996), pp. 187214; B.H. Bayerlein and P. Huber, "Protokolle des Tertors (I): Béla Kun and Lajos Mad'jar in russischen KGB-Dokumenten", The International Newsietter of Historical Studies on Comintern, Communism and Stalinism, 3, 7-8 (1996), pp. 53-71. In his polemical book about "Hotel Lux", the Russian joumalist Arkadi Vaksberg also mentions this planned trial. 
relations (OMS). Marked down for liquidation were also scores of political émigrés. The plan fell through, it is surmised, because Pyatnitsky and others refused to sign the fantastic "confessions" put in front of them. Failure in this case can hardly be attributed to Stalin. He personally intervened in the "investigations", determining the verdict in advance and said as much to Dimitrov, the General Secretary of the Comintern: "Knorin is a Polish and a German spy [...], Pyatnitsky is a Trotskyite." this in mind, it does not seem far-fetched to postulate that not only the Comintern's most important officials, but also the entire communist emigration in the Soviet Union was to be physically exterminated.

\section{DEBATES AND RESEARCH DESIDERATA}

A review of works published in the five years since Russian archival collections have become available to foreign and native Russian scholars reveals that the balance is not strictly positive. For example, the sudden cascade of new documents has reinforced a tendency which was always present in Comintern historiography: an undue emphasis on political history. Studies of the cultural and social milieus in which communists lived concentrate generally on the given national situation and rarely treat the subject on an international or Soviet level. A third shortcoming is that Comintern studies run parallel to Soviet studies but rarely intersect with them.

\section{The Historian Does not Live From the Archive Alone}

The sudden accretion of factual knowledge prompted for a time a school of writing which chose to portray the history of the Comintem primarily in chronological terms. Research was thus perceived to have fallen behind the approaches pioneered among French and, to a certain extent, among North American scholars of communist studies, namely the new questions, concepts, methods and findings presented by them when Soviet archives were still inaccessible. ${ }^{62}$ Such researchers had compensated for the lack of

${ }^{61}$ Muller, Der Fall des "Antikomintern-Blocks", pp. 193-194.

${ }^{62}$ This does not mean, of course, that similar studies were not undertaken in other countries - Italy, for example. However, because of the special conditions under which the PCI had to operate during the inter-war years, its historiography tends to concentrate on the years after 1945. See Adriano Bellone, "Storiografia e storia del PCI", Passato e presente, 12, 33 (1994), pp. 129-140, and the thematically organized bibliography in Bruno Groppo, "Les études sociologiques sur le Parti communiste italien", Communisme, 7 (1985), pp. 85-96. US studies on communism including gender aspects are, for example: Robert Schaffer, "Women and the Communist Party, USA, 1930-1940, Socialist Review, 45 (1979), pp. 73-118; Elsa Jane Dixler, "'The Woman Question': Women and the American Communist Party, 1919-1941" (Ph.D. thesis, Yale University, 1974); Van Gosse, "To Organize in Every Neighbourhood, in Every Home': The Gender Politics of American Communists between the Wars", Radical History Review. 
documents on the international level of Stalinist rule by drawing on tools from other scientific disciplines. They also applied a socio-historical approach to good effect, deriving valuable findings from many facets of social life in their native countries. French communism, above all, benefited from this problem-oriented method, and recovered the place in modem French history which was its due. Research projects of this kind investigated, for example, how the PCF was socially and politically anchored in French society and where, who voted for it, the social composition of its members and leadership, the language it used and how it communicated. Attention focused on the PCF as a social milieu, as a scrvice enterprise. ${ }^{63}$ Before Russian archives were opened such studies could be criticized for their narrow perspective: by portraying communism as a specific phenomenon in workers' everyday life, the political character of the movement was neglected, i.e. the ideological, organizational and financial dependence of the Comintern Sections on Moscow. Geoff Eley described this historiographical tendency as "history with the politics left out". ${ }^{64}$ At no stage was a Communist Party a purely national undertaking, even in terms of political culture.

Soon after the archival deposits of the Communist International became available, the pendulum seemed to swing in the opposite direction for a time, so that the history of the Comintern was defined primarily on the basis of what happened in Moscow. This development towards factual or political historiography led occasionally to sharp controversies among French experts, ${ }^{63}$ and may be of interest to those carrying out similar

63 Here there is room for only a small selection, led by Annie Kriegel, who pioneered the ethnographical approach in studies of communism. See her two volumes Communismes au miroir français. Temps, culture et sociétés en France devant le communisme (Paris, 1974), and Les communistes français dans leur premier demi-siècle 1920-1970 (Paris, 1985). See also Jean-Pierre Azéma, Antoine Prost and Jean-Pierre Rioux (eds), Le Parti communiste français des années sombres, 1938-1941. Actes du colloque organisé en octobre 1983 (Paris, 1986); Jean-Pierre Rioux, Antoine Prost and Jean-Pierre Azéma (eds), Les communistes franģais de Munich à Chateaubriand 1938-1941 (Paris, 1987); Michel Hastings, Halluin la Rouge 1919-1939. Aspects d' un communisme identitaire (Lille, 1991). For the sociology of the PCF see Jean-Paul Molinari, Les ouvriers communistes. Sociologie de l"adhésion ouvrière au PCF (Thonon-les-Bains, 1991); Bemard Pudal, Prendre parti. Pour une sociologie historique du PCF (Paris, 1989). For a review of such publications for the years 1979-1985 see "La sociologie du communisme français. Travaux parus en Iangue française depuis 1979", Commınisme, 7 (1985), pp. 65-83.

4 The Russian Review, 45 (1986), pp. 385-394.

${ }^{65}$ For example the debate around Stéphane Courtois, "Archives du communisme: mort d'une mémoire, naisssance d'une histoire", Le Débat, 77 (1994), pp. 146-156. See the contributions to this discussion: Pierre Broué, Claude Pennetier and Serge Wolikow, "Archives de Moscou: les enjeux", La Revue, 7 (1994), pp. 105-110; Sabine Jansen, "La boîte de Pandore des archives soviétiques", Vingtième Siècle, 42 (1994), pp. 97-102; François Bédarida, "Du bon usage de l'histoire du temps présent", Le Débat, 79 (1994), pp. 185-187; Pierre Vidal-Naquet, "Propos d'un méchant pamphlétaire", Le Débat, 79 (1994), pp. 187-192; Serge Wolikow, "L'histoire du communisme à l'épreuve des archives nusses", Traverse, 3 (1995), pp. 19-28. 
research elsewhere. The difficulty is that, in treating communist history on a national, international and Soviet plane, various contexts have to be intertwined and different historical approaches taken into consideration. How can the history of communism be written as a social and cultural history without losing sight of its inherently political character? Or how can it be described in terms of power structures or the Terror of the 1930s without reverting to a one-sided, manipulative discourse? Westem communists were neither will-less puppets on Moscow's strings nor did they live in self-sufficient national or regional cultures. If the historiography of communism and Stalinism is not to go into reverse gear, the interpretative models and methods behind the historical research of mentalities should not be used - as was the case when the archives remained closed - just to fill the holes caused by the lack of factual knowledge. In reality the problem is the opposite: it is precisely those approaches which emphasize social milieu and workers' culture that need to be underpinned by sufficient primary sources of a general kind. The.prerequisite material enabling wider empirical investigation only became available after 1991. Now it should be possible to fill out the "blank spots" in the international movements's history, and to depict it in all its diversity, with all its contradictions - as a unitary system which generated the suppression of its own cadres, but also acted in an integrative fashion world-wide.

In the field of Soviet studies, a profound change of outlook took place before the archives opened their doors to the West. Instead of politological concepts about the "nature" of the Soviet system, expressed for decades in models of "totalitarianism", a series of historical studies of the Russian communist system appeared. Comintern historiography has yet to tum this comer. Indeed, the questions posed by scholars writing on the history of Soviet society seem more exciting than those formulated by Comintern experts. It is about time, we feel, for Comintem studies to be integrated into the broad history of Stalinism or, as North American historians term it, the history of the "Stalin period".

The change in perspective away from "totalitarianism" was mainly the work of Stalinism experts in North America, known collectively as "revisionists". .6 The essence of the "revisionism debate" was the "historiciz-

os One of the early pioneers of a socio-historiographical approach to Soviet studies was Moshe Lewin. His writings preceded those of the "revisionists", and he is not a representative of that "school". See his The Making of the Soviet System. Essays in the Social History of Intenvar Russia (London, 1985). His historical work receives due appreciation in Roland Lew, "Grappling with Social Realities: Moshe Lewin and the Making of Social History". in Nick Lamben and Gábor T. Ritterspom (eds), Stalinism. Its Nature and Aftermath. Essays in Honour of Moshe Lewin (London [etc.], 1992), pp. 1-23. For the debate between "totalitarians" and "revisionists", which took place mainly within the American scholarly community, see The Russian Review, 45 (1986), pp. 357-431, and 46 (1987), pp. 375-427. For critical remarks on the debate see Vladimir Anderle, "Demons and Devil's Advocates: Problems in Historical Writing on the Stalin era", in Lamber, Stalinism. Its Nature and Aftermath, pp. 25-47; Hans-Henning Schröder, "Stalinismus 'von unten'? Zur Diskussion 
ation" of Stalinism, comparable to the discourse provoked by Martin Broszat in respect of National Socialism. The starting-point of the discussions was whether the growth of Soviet industry was evidence of modernization and if it therefore could be used as a parameter for periodizing an era. This led in turn to query if and to what extent a continuum existed between Lenin's and Stalin's rule, a question which was usually answered in the affirmative in the USA well into the $1970 \mathrm{~s} .{ }^{67}$ Such new approaches heralded in a belated change of direction in studies of Russian or Soviet social history, or to use the North American appellation, "New History". 68 The theses of the "revisionists" provoked virulent reactions because of their eminently political implications. The fire of the "revisionists" was directed at the "totalitarianism" paradigm hitherto uncontested in North American universities, against the predominant role of analysis which was designed for immediate political consumption and printed in joumals like Soviet Studies. ${ }^{69}$ What the revisionists "revised" was the model, assembled by political scientists, of a totalitarian Soviet state, which towered as an absolute, monolithic system above a society which had been formed by communist ideology and kept in place by the use of mass terror. The revisionist counter-argument was that the Soviet state, if at all, could only

um die gesellschaftlichen Voraussetzungen politischer Herrschaft in der Phase der Vorkriegsfunfjahrpläne", in Dietrich Geyer (ed.), Die Umwertung der sowjetischen Geschichte (Göttingen, 1991), pp. 133-166. For commentaries after the opening of the Russian archives see Wladimir Berelowitch, "La 'soviétologie' après le putsch. Vers une guérison?", Politix, 18 (1992), pp. 7-20; Nicolas Werth, "De la soviétologie en général et des archives russes en particulier"; Stéphane Courtois, "Archives du communisme: mort d'une mémoire, naissance d'une histoire", both in Le Débat, 77 (1993), pp. 127-156; Marc Lazar, "Après 1989, cet étrange communisme", in Jean Boutier and Dominique Julia (eds), Passés recomposés. Champs et chantiers de l' Histoire (Paris, 1995), pp. 243-253. For an informative review of new publications on Soviet history see Jörg Baberowksi, "Wandel und Terror: Die Sowjetunion unter Stalin 1928-1941", Jahrbïcher für Geschichte Osteuropas, 43 (1995), pp. 97-129. An "anti-revisionist" review of interpretations of the Stalinist Terror is provided by Markus Wehner, "Stalinistischer Terror. Genese und Praxis der kommunistischen Gewaltherrschaft in der Sowjetunion 1917-1953", Aus Politik und Zeitgeschichte (Beilage zur Wochenzeitung Das Parlament), 6 September 1996, pp. 15-28.

${ }^{67}$ Seminal works which challenged the "totalitarianism" model were Stephen F. Cohen, Bukharin and the Bolshevik Revolution. A Political Biography 1888-1938 (New York, 1971), and Robert C. Tucker (ed.), Stalinism. Essays in Historical Interpretation (New York, 1977).

6s In comparison to general historiography in the USA, new methods or concepts were only slowly adopted in American Soviet studies. See Terence Emmons, "Then and Now in the Pages of the American Historical Review and Elsewhere: A Few Centennial Notes", American Historical Review, 100, 4 (1995), pp. 1136-1149.

69 The dominance of teleological standpoints was underlined in a stocktaking article on Sovietology after the collapse of the Soviet Union. See Charles King, "Review Article: Post-Sovietology: Area Studies or Social Science?", International Affairs, 70, 2 (1994), pp. 291-297. For a general account of the employment of totalitarian models in writings on Soviet history see Abbot Gleason, Totalitarianism: The Inner History of the Cold War (New York, 1995). 
then be termed "totalitarian" by virtue of the intentions it held, especially as everyday life was characterized by the chaotic incompetence and uncoordinated measures of government agencies. Further, the Terror, supposedly directed from a central base, proved on analysis to have been neither uniform nor thoroughgoing. The "revisionists" were at pains to demonstrate that the dynamics of social antagonism, seen as part of society's development in those years, provided the key to the sense behind the Terror. For many who read the treatises of the "revisionists", the Terror seemed to have lost many of its daemonic attributes and "irrationality". Furthermore, Stalinism was not only a "Revolution from above" (Robert Tucker), but contained elements of a "Revolution from below" by giving the Terror an anti-bureaucratic and plebeian thrust (J.A. Getty, Gábor Rittersporn). ${ }^{70}$ As one analysis of the victims reveals, the Terror was directed, in the first place, at elites, and, with some support from "below", against local potentates in particular. ${ }^{71}$ Sheila Fitzpatrick has pointed to the formation of a new class of cadres advancing up the social ladder engineers, managers, party and administrative officials. The extermination of the old elite cleared the way for the careers of the countless ambitious, for the vydvizhency, who profited from the Terror by occupying the posts of experienced predecessors whom the mass repression had engulfed.72 "Poor peasant's son elected to Central Committee" or "Once illiterate peasant wife, now engineer" - such were the symbolic depictions of advancement opportunities propagated in the Soviet press. ${ }^{73}$

\footnotetext{
70 John A. Getty, Origins of the Great Purges. The Soviet Communist Party Reconsidered, 1933-1938 (Cambridge [etc.], 1985); Gábor T. Ritterspom, Stalinist Simplifications and Soviet Complications. Social Tension and Political Conflicts in the USSR 1933-1953 (Paris [etc.], 1988). It is important to recall that this new interpretation of the Terror was formulated before Russian archives became available. Before 1991 Western scholars had to rely on the so-called Smolensk party archive. For findings based on material released subsequently see John A. Getty and Roberta T. Manning (eds), Stalinist Terror. New Perspectives (Cambridge, MA, 1993).

"I John A. Getty, Gábor T. Ritterspom and Viktor N. Zemskov, "Victims of the Soviet Penal System in the Pre-war Years. A First Approach on the Basis of Archival Evidence", The American Historical Review, 98, 4 (1993), p. 1043.

${ }^{72}$ Sheila Fitzpatrick (ed.), Cultural Revolution in Ritssia, 1928-1931 (Bloomington [etc.], 1978), especially the chapter "Cultural Revolution as Class War", pp. 8-40. Sce also her The Cultural Front. Pow'er and Culture in Revolutionary Russia (Ithaca [etc.], 1992), especially the chapter "Stalin and the Making of a New Elite". In German-speaking countries Hans-Henning Schröder adopted a similar standpoint: see his Industrialisierung and Partejbürokratie in der Sowjetunion. Ein sozialgeschichtlicher Versuch uber die Anfangsphase des Stalinismus (1928-1934) (Berlin, 1988).

${ }^{73}$ Revealing in this context are remarks by Stalin to the effect that "the secondary cadres" were decisive in pushing through the policy propagated by Stalin, Molotov, Voroshilov and others against Trotsky and Bukharin, who, according to the Stalinist leadership, had not bothered about the future of these cadres. (Note from Dimitrov's diary, 7 November 1937. Sovershenno sekretno (Moscow) 1990, no. 12.) See also the series of pictures by Brigitte Studer in "Ein Bauemmädchen wird Brigadechef. Ein stalinistischer Lebensentwurf"., Traverse, 3 (1995), pp. 63-70.
} 
Another point argued by the "revisionists" is that the Terror, in its massive scale and the chaotic forms it often took, was not planned by Stalin or the state. It was rather an explosion of social conflicts which became out of hand, a kind of incipient civil war within the state apparatus which the leadership could not contain. ${ }^{74}$ Describing the Terror as an expression of social conflict makes it appear a comprehensible subject open for analysis. However, as the mass repression threatened to destroy the very state machinery which had unleashed it, the Terror showed its "irrational" face once more. ${ }^{75}$ Recent articles based on new sources seem to confirm the improvised nature of the mass persecution. One scholar, commenting on the documents of the Politbureau in the 1930s, interprets the policies of the Stalinist leadership as being "experimental": the ruling circle proceeded pragmatically, took situations as they came, and developed policy according to institutional interests or informal, personal contacts within the Politbureau. ${ }^{76}$

The imagery of the Terror interpreted by Gábor Rittersporn has inspired a recent publication on the first great show trial of ex-party leaders in 1936. ${ }^{\pi}$ The images of the enemy (Feindbilder) appearing in the forced "confessions" served to provide an explanation for what was concrete and tangible - the disorganized state of the Soviet system. It was essential for the Stalinist leadership to manufacture a plausible reason for the dysfunctional condition in the state and party apparatus. This "enlightenment" was all the more necessary as the party leadership did not comprehend how things could have come to this pass, but knew that the public saw the effects of the bureaucratic chaos everywhere and expected an explanatory response from on high. And "Trotskyism", while no longer a political current of any consequence in the Soviet Union, was taken to be the ideal daemonic image for mass consumption. These paranoid interpretative models, fixed far in advance of the actual trial, became the official explanation for real problems and, subsequently, the reality internalized by the ruling caste. Taking account of the conclusions reached in the "revisionism" debate, the Comintern, it can be argued, was assigned the role of a Trojan horse during the Terror, symbolizing the threat to the Soviets posed by foreign powers. This scenario seems plausible when the following theses of the "revisionists" are accepted:

"See Ritterspom's volume, Stalinist Simplifications, and his article, "Nouvelles recherches, vieux problèmes", Revue des Etudes slaves (Paris), 64, 1 (1992), pp. 9-25.

75 This is especially the case with Ritterspom's "revisionism", which often seems fuelled by a taste for the surprising and the apparently contradictory. See his "The Omnipresent Conspiracy: On Soviet Imagery of Politics and Social Relations in the 1930s", in Getty and Manning, Stalinist Terror, pp. 99-115.

${ }^{76}$ See Khlevniuk, Le cercle du Kremlin.

$n$ Fred E. Schrader, Der Moskauer Prozeß 1936. Zur Sozialgeschichte cines politischen Feindbildes (Frankfurt a.M. [etc.], 1995). 
- The Yezhovshtshina represented a populistic, anti-bureaucratic offensive, which, while uncontrollable in the end, was originally conceived as a means of disciplining the party buraucracy, and, in a wider sense, the entire population.

- The great show trials against former oppositionists were carefully planned productions which transported archaic and daemonic images of evil that corresponded to negative prototypes present in the collective imagination of the Russian masses. ${ }^{78}$

Under these circumstances, the Comintern apparat and foreign communists resident in the USSR went under in the bedlam of mounting social and political tensions. Already written off as a political force, the cadres of international communism had one final part to play in the drama - as "material" for the insatiable machinery of the Terror. Within the Comintern the dynamism of repression was not only generated by orders from above. Denunciations were also means to an end in the struggle for power and position, and were often set in train by ambitious cadres who hoped to gain personal advantage by behaving "vigilantly": a post now free because its previous holder was behind bars, or a room in the Comintern's "Hotel Lux" vacated for the same reasons. A rising generation of new cadres, educated in ECCI's schools, saw the liquidation of the "old guard" as a personal opportunity to shin up the party or Comintern hierarchy. In this sense, the Communist Party can also be perceived as the route of social advancement for young proletarians who were denied such prospects in their native countries.

\section{The Comintern: Straitjacket and Horizon of Hope}

A question of great relevance to our topic runs as follows: how was it possible for generations that tens of thousands of critically-minded persons joined or supported one or more of the many organizations founded by the Comintern? What was behind the success of the Stalinist system? In the world-within-world of adherence to the Communist International its followers were given a set of answers to explain social and political reality. What were the components of the sense of identity which communists adopted and valued? Within the framework of a global twin-project (constructing a new society, engineering the soul of homo sovieticus), those receptive for the Soviet message were offered a Promethean life-goal

\footnotetext{
"See the thesis put forward by Getty, "Origins", and Ritterspom, Stalinist Simplifications. See also Nicolas Werth, Les procès de Moscou (Brussels, 1987), which relies extensively on Getty's thesis. Werth also borrows central arguments of the "revisionists" in the chapters dealing with the Terror (1934-1939) in his Histoire de L'Union Soviétique. De l'enipire russe à la Conmunauté des Etats indépendents 1900-1991 (Paris, 2nd ed., 1992; 1st pub. 1990).
} 
and a code of political behaviour. As mentioned above, Soviet citizens from a humble background received a chance to better themselves by occupying one of the many posts vacated during the period of mass arrests. The unique set of cultural values propagated by the system provided the recipients with a paradigm of conformist attributes, which over time formed a part of the individual communist's personality. However, such guidelines were also restrictive. How social reality was defined, naturally served the interest of the regime and the party, while at the same time assisting the individual to acquire a coherent identity. When an individual had internalized these values, codes and norms, could master the semantic nuances ("speaking bolshevik") ${ }^{79}$ and think and act according to them, only then was he or she in a position to participate fully in the activities of the world movement, only then was a party member considered to be a socially competent Communist. Some recent publications have concerned themselves with the model roles and model values of the Stalinist era ${ }^{80}$ in our view one of the most promising approaches in fathoming the fascination of communism for millions. What indeed were the characteristics expected of a cadre, those attributes we find in the innumerable evaluations present in the files of ECCI's Cadres Department or, internalized, in the "autobiographies" written for the Comintern? Or in the interrogation papers dictated to the prisoner by NKVD officers? Or in the documents relating to "criticism and self-criticism" sessions before the party cell evidence comparable to the inquisition protocols that Carlo Ginzburg evaluated as historical sources? ${ }^{81}$ Papers of this kind are admirably suited for an investigation of the following phenomena from the inner life of communism:

- mental concepts and behavioural patterns;

- the collison of differing conceptions of public and private spheres;

- how personality is formed and how it relates to society;

- collective representations of society and exemplary values in different cultures.

The cadre under scrutiny does not emerge as an "individual" from such accounts, but the outline of what he or she should be in the party sense.

${ }^{79}$ Kotkin, Magnetic Mountain.

*o See the two essays by Claude Pennetier and Bernard Pudal, Genèses, 23 (1996): “Ecrire son autobiographie (les autobiographies communistes d'institution, 1931-1939)", pp. 5375, and "La 'vérification' ('encadrement biographique communiste dans l'entre-deuxguerres)", pp. 145-163. Brigitte Studer and Berthold Unfried are shortly to complete a project on this theme: "Kategorien der Kultur/Figuren der Vorstellungswelt des Stalinismus: die Komintem der dreißiger Jahre als Lebensform".

" "Der Inquisitor als Anthropologe", in Rebekka Habermas and Niels Minkmar (eds), Das Schwein des Häuptlings. Beitrdge zur Historischen Anthropologie (Berlin, 1995), pp. 42-55. 
Future research could address the question to what degree this narrow scope for action precluded deviant behaviour. Did the adoption of Stalinist argumentation patterns influence or change personality at its core, the self? A question which seems all the more relevant considering the hypothesis that Stalinism also intended to occupy that residual portion of the self from which an oppositional stance could spring. That the imposition of Stalinist thought-patterns did not erase all vestiges of the developed self is confirmed by the actions of many critical communists who turned their backs on the movement. Despite the institutionalized, code-like language and formula permeating all documentation from the Comintem's Cadres Department, the autobiographies deposited there sometimes contain subtle phraseology which indicate that not every cadre adhered at all times to canonized communist standards. Having culled so much from this type of "secretized" biographical data, the next step is to probe the possibilities for the individual to retain his personality within a system which permitted only a schematized social identity in harmony with Stalinist norms. Western employees of the Comintern and political emigrants in the Soviet Union felt this dilemma acutely: they were expected to adjust to daily life in Russia, which was novel and only understandable with the passage of time, if ever. How did these foreigners come to terms with a society that did not recognize the division between public and private spheres, a basic characteristic of developed civil society in the West? Or how did communist women from abroad reconcile their commitment to equality between the sexes with the return to conservative family values in the Soviet Union after 1935 ?

It would be a pity to use the new archival material which offers so many insights into the world of the Communist International merely to supplement our factual knowledge. The historiography of the communist movement will only then reach a qualitatively higher plane when research is enriched with new questions, and approaches which widen the framework of previous research - the primacy of political history. In addressing the following themes, historical research on the Comintern will cease to be the preserve of specialists:

- how public and private spheres in society were delineated;

- how identity was "constructed" in the Soviet version of modern society;

- how gender difference and gender identity were generated.

By integrating these and similar themes of contemporary social history, the findings of communist history can be made accessible to a larger audience than just the small circle of specialists. Due to the rich primary sources now available, a comprehensive "historicization" of the Stalin era is now feasible, provided, of course, that the archival rules of access in Russia do not deteriorate any further. There is no shortage of methods or approaches to make the subject comprehensible and interesting to groups 
of scholars outside the small community of Comintern experts. In the last resort, it depends no longer on the archival deposits but on the historians themselves whether or not Comintern history remains a happy hunting ground for the few. 